
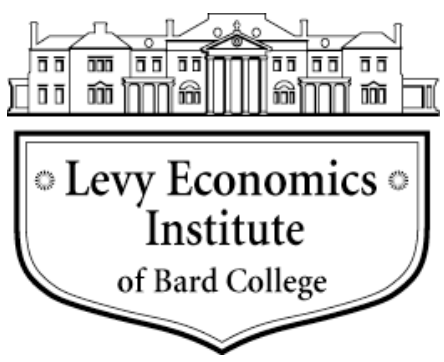

Working Paper No. 724

\title{
Post-Keynesian Institutionalism after the Great Recession
}

by

\author{
Charles J. Whalen* \\ Congressional Budget Office
}

May 2012

\begin{abstract}
*E-mail: Charles.Whalen@cbo.gov. This paper was prepared for a forthcoming special issue of Intervention: European Journal of Economics and Economic Policies (2013, No. 1; Marc Lavoie and Phil O'Hara, guest editors) and provides the basis for the author's contribution to "Minsky: Global Financial Fragility and the Development of Capitalist Finance," a conference organized by the Levy Economics Institute of Bard College in collaboration with The Institute of Economics and The Center for Political Economics Studies of Nankai University, Tianjin, China, June 9-10, 2012. The views expressed in the paper are those of the author and should not be interpreted as those of the Congressional Budget Office. The author thanks Glen Atkinson, John Henry, Jeff Kling, Kim Kowalewski, Robert Shackleton, Linda Whalen, and Tim Wunder for helpful comments.
\end{abstract}

The Levy Economics Institute Working Paper Collection presents research in progress by Levy Institute scholars and conference participants. The purpose of the series is to disseminate ideas to and elicit comments from academics and professionals.

Levy Economics Institute of Bard College, founded in 1986, is a nonprofit, nonpartisan, independently funded research organization devoted to public service. Through scholarship and economic research it generates viable, effective public policy responses to important economic problems that profoundly affect the quality of life in the United States and abroad.

Levy Economics Institute

P.O. Box 5000

Annandale-on-Hudson, NY 12504-5000

http://www.levyinstitute.org

Copyright (C) Levy Economics Institute 2012 All rights reserved 


\begin{abstract}
This paper surveys the context and contours of contemporary Post-Keynesian Institutionalism (PKI). It begins by reviewing recent criticism of conventional economics by prominent economists as well as examining, within the current context, important research that paved the way for PKI. It then sketches essential elements of PKI - drawing heavily on the contributions of Hyman Minsky — and identifies directions for future research. Although there is much room for further development, PKI offers a promising starting point for economics after the Great Recession.
\end{abstract}

Keywords: Post-Keynesian Institutionalism; Institutional Economics; Post-Keynesian Economics; Financial Instability; Money-Manager Capitalism; Hyman Minsky

JEL Classifications: B25, B52, E12, E32 


\section{INTRODUCTION}

In the mid-1970s, Wallace C. Peterson used the occasion of an address before institutional economists to argue that institutionalism and the economics of John Maynard Keynes can be viewed as "two trains on parallel tracks toward a common destination" (Peterson 1977, 202). Today, in the wake of the Great Recession - the worst global economic downturn since the 1930s - those trains have finally reached the station. Their arrival is none too soon for economics and the world economy.

The common destination of institutionalism and the economics of Keynes, the latter of which is currently called Post-Keynesian economics, is Post-Keynesian Institutionalism (PKI). This article surveys the context and contours of contemporary PKI. It begins by reviewing recent criticism of conventional economics by prominent economists as well as examining (against the backdrop of the current context) important research that paved the way for PKI today. Then it sketches essential elements of PKI-drawing heavily on the contributions of Hyman P. Minsky — and identifies directions for future research. Although there is room for much additional work on many topics, PKI offers a promising starting point for economics after the Great Recession.

\section{ECONOMICS AND THE RECENT ECONOMIC CRISIS}

The financial crisis that ran from late 2007 through early 2009 did more than traumatize the world economy; it drew widespread attention to some major shortcomings of conventional economics. Paul Krugman pointed out those weaknesses in a number of public lectures and in the pages of The New York Times, but he was not alone. Forced to confront the reality of the Great Recession, a number of prominent scholars and policymakers also joined the chorus.

In the summer of 2009, on the heels of his receipt of the Nobel memorial award in economic sciences, Krugman delivered a series of lectures at the London School of Economics. During one of them, he argued that "most of what economists have done in macroeconomics for the past thirty or so years has turned out to be spectacularly useless at best, and positively harmful in some cases" (Krugman 2009a). Krugman advised a return to Keynes for crucial insights that could put economics on a more useful path. He also suggested a way forward, observing that Joseph A. Schumpeter and other prominent economists missed a valuable 
opportunity by failing to integrate Keynes's economics with Pre-Keynesian scholarshipdominated by the work of institutionalists—on business cycles.

A few months later, Krugman (2009b) wrote an article for The New York Times that explained why economists failed to anticipate the global financial crisis. He argued that economists studying the financial sector believed its markets were efficient and inherently stable, and that macroeconomists thought if there was instability then monetary policy alone would be sufficient to set things right. Krugman also argued that at the heart of the profession's failure was its emphasis on rigor, rather than relevance- that is, economics had been weakened by "the desire for an all-encompassing, intellectually elegant approach that also gave economists a chance to show off their mathematical prowess." Describing what economics needs to move forward, Krugman offered two recommendations in addition to again making the case for renewed attention to Keynes: scholarship that questions the efficient-market view of the financial sector, and research that incorporates the realities of finance into macroeconomics.

Krugman's main points are reinforced by other prominent academics and practitioners. Joseph E. Stiglitz (2010, 238), also a recipient of the Nobel award, maintains that economists have become "blinded by their faith in free markets." Franklin Allen, of the Wharton School, argues that most economists were caught flat-footed by the financial crisis because to them it was unimaginable. "It's not just that they missed it; they positively denied it would happen," says Allen, who places much of the blame on the finance world's fascination with the efficient market hypothesis. ${ }^{1}$

Ricardo J. Caballero, chairman of the economics department at the Massachusetts Institute of Technology from 2008-2011, focuses his critique on macroeconomics. What concerns him most is the core of macroeconomic theory, the so-called dynamic stochastic general-equilibrium (DSGE) approach. According to Caballero, DSGE "has become so mesmerized with its own internal logic that it has begun to confuse the precision it has achieved about its own world with the precision that it has about the real one" (Caballero 2010, 85). ${ }^{2}$

Lawrence H. Summers, based at Harvard University and well-known for his academic and policy work, highlights weaknesses of conventional economics at the intersection of

\footnotetext{
${ }^{1}$ Quoted in "Why Economists Failed to Predict the Financial Crisis," Knowledge@ Wharton, May 13, 2009. http://knowledge. wharton.upenn.edu/article.cfm?articleid=2234

2 Although Caballero suggests the profession's core "has begun" to confuse theory and reality, the observation that economists put rigor before relevance is, of course, not new. See, for example Gordon (1976).
} 
macroeconomics and finance. He argues that macroeconomics has not sufficiently adapted to changes in financial markets and new insights from behavioral finance. He adds: "I think economics knows a fair amount. But I also think economics has forgotten a fair amount that's relevant, and it has been distracted by an enormous amount" (Summers 2011).

Economists outside the United States also turned a critical eye toward their profession as a consequence of the financial crisis and Great Recession. For example, Willem Buiter (2009), chief economist at Citigroup in London, writes that conventional economics became "a severe handicap" when central banks had to switch gears from targeting inflation to maintaining financial stability. According to Buiter, most economic theorists adopted a "complete markets" paradigm and an extreme version of the efficient market hypothesis. Their theories "not only did not allow questions about insolvency and illiquidity to be answered; they did not allow such questions to be asked." 3

\section{PKI BEFORE THE GREAT RECESSION}

The attention Krugman and others have drawn to shortcomings of conventional economics puts new light on the longstanding efforts of institutionalists and Post-Keynesians to forge a PKI. With mainstream economists now questioning aspects of the conventional wisdom of their discipline, it becomes instructive to look at some of those earlier efforts. (A comprehensive review is, of course, not possible here.)

In many respects, institutionalism and Post-Keynesian economics were destined to come together. For example, the pioneering work of Keynes and John R. Commons-a major early contributor to institutionalism-shared much in common, especially an interest in stabilizing capitalism and ensuring its viability as a superior alternative to socialism and fascism. In fact, Keynes's biographer identifies Commons as an important influence on Keynes in the 1920s (Skidelsky 2003, 368), and economist Steven Kates demonstrates that Commons-partly through his student Harlan McCracken—had a profound influence on the line of reasoning pursued by Keynes in The General Theory (Kates 2011). ${ }^{4}$

\footnotetext{
${ }^{3}$ Willem Buiter, "The Unfortunate Uselessness of Most 'State of the Art' Academic Monetary Economics," Vox, March 6, 2009. http://www.voxeu.org/index.php?q=node/3210

${ }^{4}$ For further discussion of Commons's influence on Keynes, see Whalen (2008a). For more on the common ground shared by Commons and Keynes, see Atkinson and Oleson (1998), Chasse (1991), Crotty (1990), and Tymoigne (2003).
} 
The 1970s and early 1980s were a productive period of exploration for scholars interested in the possibility of a PKI. At that time, the institutionalist tradition had fewer followers and less professional influence than it did in the first half of the $20^{\text {th }}$ century, but institutionalism still attracted innovative thinkers and even included some illustrious economists (such as John Kenneth Galbraith and Robert Heilbroner) within its camp. Meanwhile, PostKeynesianism was gaining its identity as a tradition shaped by a small group of economists in the United States and the United Kingdom—including Joan Robinson, Sidney Weintraub, Paul Davidson, and Alfred S. Eichner-and rooted in aspects of Keynes's scholarship not easily accommodated in the neoclassical synthesis that emerged after World War II.

Among the economists looking for a fusion of insitutionalism and Post-Keynesianism at that time were Peterson, Dudley Dillard, W. Robert Brazelton, and Robert R. Keller. Peterson (1977) identified a set of core ideas that he saw as the foundation of both traditions. They include the following: economic activity must be studied as an ever-evolving process; economic behavior rests heavily on widely held conventions and expectations about a fundamentally uncertain future; capitalism has no inherent tendency toward economic equilibrium; conflict is an intrinsic part of social life; money is the key institution of modern capitalism; and the state is a vital economic actor and can be used for good or for ill. Dillard (1980) stressed that both traditions give special attention to how financial institutions and profit expectations are factors explaining business cycles. Brazelton (1981) observed that institutionalists and Post-Keynesians have a common interest in real-world wage and price determination, including the institutional determinants of wages and the macroeconomic significance of mark-up pricing. Keller (1983) added that the traditions are complementary because institutionalism offered a deeper consideration of the role of government in the economy, while Post-Keynesianism offered a more fully developed analysis of economic problems such as stagflation.

In the United States in early 1980s, the time certainly seemed right for institutionalists and Post-Keynesians to unite. The economy had just experienced a period of extraordinarily high inflation and was confronting what was at that point the worst downturn since the Great Depression. Ray Marshall (1983), a University of Texas economist and former US Secretary of Labor, surveyed the landscape of discredited economic theories-including monetarism and supply-side economics - and called for a synthesis of institutionalism and Post-Keynesian economics. 
Charles K. Wilber and Kenneth P. Jameson, who were then both at the University of Notre Dame, answered Marshall's call with An Inquiry into the Poverty of Economics (Wilber and Jameson 1983). It explicitly offers PKI as an alternative to conventional economics and other economic paradigms. In particular, it describes PKI as holistic (in other words, it sees a world in which institutions shape economic life and where the "economy" is not neatly separated from other social spheres), systemic (interdependencies are pervasive), evolutionary, and driven by an interest in understanding and resolving real-world economic problems. The book also builds on John Kenneth Galbraith's analysis of the "bimodal economy"—which describes the nature and interaction of a US economy with about a thousand large corporations at its core and many thousands of small firms at its periphery-and uses that analysis and other institutionalist and Post-Keynesian insights to address the problem of stagflation.

Although their PKI foundation was well-constructed, Wilber and Jameson failed to receive much attention because their book appeared just as inflation was being beaten down. They had identified an important, real-world problem, but PKI needed a new focus if it was to advance after the mid-1980s. The economics of Hyman Minsky provided that focus: the study of economic instability, with special emphasis on the interaction of finance and macroeconomics.

Minsky was a monetary economist interested in how financial institutions affect business cycles and the trajectory of US economic development. Although he considered himself a Keynesian, Minsky's scholarship contains evidence of a much wider set of influences, including the evolutionary economics of Joseph Schumpeter and the institutionalism of Wesley C. Mitchell (see, for example, Minsky 1990). In fact, Minsky wrote in 1969 that monetary economics "cannot escape being institutional economics" (Minsky 1969, 225). He was accepted by his colleagues as both a Post-Keynesian and an institutionalist, and used receipt of the Veblen-Commons Award from the Association for Evolutionary Economics as an opportunity to stress not only the affinity between Keynes and Commons but also the continuing relevance of that affinity (Minsky 1996, 357).

Minsky is best known for his financial instability hypothesis, but also devoted much of the last decade of his life (while serving as a distinguished scholar at the Jerome Levy Economics Institute) to examining the emergence of what he called money manager capitalism. The financial instability hypothesis-which Minsky developed early in his career and polished while teaching at Washington University_explains how financial fragility is endogenously 
generated during periods of economic growth, leading to credit crunches and possibly even severe economic downturns. ${ }^{5}$ Money manager capitalism is the term Minsky coined to highlight the dominant position that institutional investors came to hold in the US economy in the 1980s, a position they used to influence both corporate decision-making and public policy. ${ }^{6}$

Today, a number of economists see themselves as institutionalists and Post-Keynesians. ${ }^{7}$ Not all of them build on the work of Minsky, but many do. That is not surprising. Indeed, in the midst of the recent financial crisis, economist Robert Pollin wrote, "We are all Minskyites now" (Pollin 2008). The current dissatisfaction with conventional economics certainly provides an opening for PKI.

\section{SOME ESSENTIALS OF PKI}

PKI can be described today as an intellectual tradition that fuses adherence to an institutionalist viewpoint with the use of some powerful Post-Keynesian tools of analysis. In particular, the following are some essential elements of PKI. ${ }^{8}$

\section{PKI Rests on an Institutionalist Foundation}

According to William M. Dugger (1996), institutionalists define economics as the study of realworld processes of social provisioning and the definition provides their school of thought with its underpinnings. PKI is also grounded in that definition.

Some important implications of Dugger's definition should be readily apparent. PKI focuses on actual economic life; its adherents recognize that all theory is an abstraction from a complex world, but they seek theories that incorporate realistic assumptions, even if less realism would enable construction of more formal models. PKI adopts a broad conception of its subject matter; social provisioning involves more than buying and selling, and more than pursuing goals by means of maximization. (As Wilber and Jameson stress, economic life is holistic and systemic, so the boundaries between the economy and other social spheres are always

\footnotetext{
${ }^{5}$ For statements of the financial instability hypothesis, see, for example, Minsky (1992), Minsky (1982), and Minsky (1975).

${ }^{6}$ For a discussion of money manager capitalism, see, for example, Minsky (1996).

${ }^{7}$ See, for example, Kaboub (2011), Liang (2011), Niggle (2006), Todorova (2009), Zalewski and Whalen (2010). and Waller (2005).

${ }^{8}$ This section is not comprehensive. For example, an extended examination of PKI elements would include a discussion of the microeconomics of administered prices as well as attention to an institutionally grounded approach to labor markets. For important contributions on those topics, see Lee (1996) and Appelbaum (1979), respectively.
} 
imprecise.) And PKI emphasizes that economic life is dynamic: economic activity occurs in a world with a past (that conditions but does not entirely predetermine subsequent events), present, and future-and nearly all aspects of the economic system are constantly evolving.

Other implications may be less obvious, but are still significant. For example, PKI recognizes that people are social creatures, who act in a world of uncertainty. Although people often act as individuals, the ends and means they pursue-indeed, even their understanding of the world around them-are largely socially constructed. In other words, human behavior is shaped by social engagement and the influence of social institutions. The recognition that people are social creatures also underscores the reality that economic life involves interaction, which frequently involves cooperation, but also involves other forms of interaction, including conflict, dependence, care, and nurturing. ${ }^{9}$ That recognition also highlights the pervasiveness of power relations and the limitations that social life necessarily places on individual freedom. ${ }^{10}$ In addition, an uncertain future means that people act on the basis of expectations, not absolute certainty; it also means that people frequently rely on habits and social conventions; expectations are often unmet; lessons are learned through experience; and both ends and means are subject to constant reconsideration. ${ }^{11}$

Another implication is that PKI sees institutions, not impersonal forces or universal laws of nature, as the balancing wheel of the economy. To be sure, societies often rely on the price system to influence the allocation of resources. But the price system - the market mechanismis itself a social institution. Societies create markets and other institutions to help people accomplish more than would be possible otherwise, to resolve conflicts, and to reduce uncertainty. Understanding the institutional setting (including key features of the economy's structure as well as actual processes of wage and price setting) is an essential part of understanding real-world economic activity. ${ }^{12}$

\footnotetext{
${ }^{9}$ For further discussion of such interaction, see, for example, Folbre (2001) and May (1996).

${ }^{10}$ For an institutionalist discussion of power, see Galbraith (1979). For more on freedom and the limitations-and opportunities - associated with a social existence, see the section below on government's role in the economy.

${ }^{11}$ Uncertainty and expectations combine in Commons's foundational concept of "futurity;" see Atkinson and Whalen (2011).

${ }^{12}$ For a similar view, see Piore and Sable (1984), especially p. 4. See also Dillard (1986), Foster (1981), and Thompson (1967).
} 


\section{PKI Recognizes Constant Change as the Inescapable Reality of Capitalism}

In economics and political science, it recently became fashionable to draw attention to the varieties of capitalism. ${ }^{13}$ Institutional economics has always appreciated that capitalism varies across countries and over time. ${ }^{14} \mathrm{PKI}$ has, as well. Indeed, post-Keynesian institutionalists often quote Minsky's quip, "Capitalism comes in at least as many varieties as Heinz has of pickles."15

The price system often exhibits equilibrating tendencies, but market dynamics can also involve cumulative causation and hysteresis, which means that real-world markets may not rapidly or even fully correct themselves in the wake of a downturn. In PKI, rational decisionmaking about an uncertain future can lead to booms, severe downturns, and economies that stall at far below potential for extended periods. ${ }^{16}$ Moreover, economic change occurs even when the economy is stuck in a slump. As Schumpeter (1976 [1942], 83) writes, "Creative destruction is the essential fact of capitalism."

Schumpeter (1976 [1942], 82-85) stresses that the dynamic force of capitalism "incessantly revolutionizes the economic structure from within" (emphasis in original). He adds: "The fundamental impulse that sets and keeps the capitalist engine in motion comes from the new consumers' goods, the new methods of production or transportation, the new markets, the new forms of industrial organization that capitalist enterprise creates." Moreover, creative destruction is especially relevant to the financial sector. As Minsky $(1993,106)$ writes, "Nowhere is evolution, change, and Schumpeterian entrepreneurship more evident than in banking and finance, and nowhere is the drive for profits more clearly the factor making for change."

\section{PKI Begins with a Wall Street Paradigm}

Conventional economics is constructed around the notion of a barter economy. The starting point is that of a village fair: Money, finance, capital assets, and production can all be added, but the paradigm assumes that the central features of capitalism can be grasped without them. In

\footnotetext{
${ }^{13}$ On the varieties of capitalism, see Hall and Soskice (2001), for example.

${ }^{14}$ For example, Commons $(1934,766)$ writes: "Capitalism is not a static or single concept"; see Commons (1934, 763-908) and Atkinson and Whalen (2011).

15 The reference, of course, is to the Heinz slogan, "57 Varieties."

${ }^{16}$ As Minsky $(1986,177)$ writes, there may be a path out of a severe downturn and back to full employment by means of price flexibility and wage cuts, but if there is such a path, "it may well go by way of hell."
} 
contrast, the Wall Street paradigm—described most fully by Minsky (1975), but also implicit in institutionalism and in Keynes-recognizes that capitalism is driven by the pursuit of financial gain, that production precedes market exchange, and that finance precedes production.

The Wall Street (or financial) paradigm studies the dynamics of contemporary capitalism by characterizing all economic units by their financial portfolios. In all sectors, people and organizations constantly face the need to decide what assets to acquire and how to finance them. The result is a dynamic, paper world of financial liabilities, cash-flow commitments, and interrelated balance sheets - all dependent on expectations made against the backdrop of an uncertain future and an irreversible past (Minsky 1969, 227).

The recent financial crisis - in which over-indebtedness played an important role- has highlighted the value of looking at the economy through the lens of the Wall Street paradigm. Thus, it is not surprising to find that approach used by many contemporary economic analysts. For example, Moody's Analytics examined the state of the US economy in May 2011 by reviewing the balance sheets of corporations, households, banks, and the federal government (Zandi 2011). ${ }^{17}$

The Wall Street paradigm is also implicit in the "financial balances" model used by economists at Goldman Sachs to examine the US economic outlook. That model uses a framework championed by the late Wynne Godley, a Cambridge University economist and Levy Economics Institute colleague of Minsky during the 1990s, which focuses on the gaps between income and spending within the different sectors of the economy. ${ }^{18}$ Although imbalances of the different sectors must add up to zero at the end of each period for the purpose of national income accounting (that is, the private sector balance plus the public sector balance must equal the US current account balance), the Goldman Sachs economists-Hatzius and Stehn (2011a; 2011b)_-stress that this need not be the case in terms of spending intentions:

If all sectors taken together try to reduce their financial balance-i.e. increase spending more than income and finance the difference by borrowing more or running down their cash balances - the economy will tend to grow above

\footnotetext{
${ }^{17}$ The point here is not to suggest that the Wall Street paradigm is new (only that it is relevant and used by today's analysts). In fact, even neoclassical Keynesians used this approach decades ago; see, for example, Brainard and Tobin (1968).

18 The Godley framework has also been used by institutionalists and Post-Keynesians to stress that economists' conventional notion of "national saving" (private saving + government saving + foreign saving) is misleading, since if the government sector is saving, then some other sector (or sectors) must not be, by definition. See, for example, Scott Fullwiler, "The Sector Financial Balances Model of Aggregate Demand," The Wall Street Pit, July 18, 2009. http://wallstreetpit.com/8568-the-sector-financial-balances-model-of-aggregate-demand
} 
potential. Conversely, if all sectors taken together try to increase their financial balance-i.e. increase spending less than income and use the difference to accumulate cash or pay down debt-the economy will tend to grow below potential. This suggests that we may be able to predict the ups and downs of the business cycle if we can predict the ups and downs of the ex ante financial balances of the different sectors.

\section{PKI Approaches Macroeconomics from a Business Cycle Perspective}

The business cycle has been part of life in a capitalist economy since at least the early $19^{\text {th }}$ century. But PKI goes beyond arguing that capitalism is prone to booms and downturns. It argues that the endogenous generation of business cycles "is a basic characteristic" of contemporary capitalism (Minsky 1975, 164).

PKI does not offer a single explanation for all cycles. Indeed, Wesley C. Mitchell, institutional economist and founder of the National Bureau of Economic Research, stressed that "each new cycle presents idiosyncrasies" (Mitchell 1941, ix). But credit expansions and contractions have often been important factors in the business-cycle literature of institutionalism. The cycle perspective of PKI is also informed by the insights of Minsky, who traces business cycles to the interplay of two features of the economy that have become nearly synonymous with modern capitalism: a) capital assets that are expensive and long-lived, and b) institutions of finance that allow short-term financing and position taking (see, for example, Minsky 1975).

PKI draws on the insights of Mitchell, Minsky, and other institutionalists and PostKeynesians for the purposes of developing and refining a multidimensional, integrated, and evolutionary analysis of the business cycle. Such an analysis aims to explain expansion, boom, crisis, downturn, and recovery in a coherent fashion. It also aims to identify why each of those states is transitory, how one state develops into the next, and what can be done (by means of institutional adjustment) to dampen downturns and sustain periods of prosperity.

\section{PKI Incorporates the Financial Instability Hypothesis into its Analyses}

That hypothesis represents an alternative to the efficient market hypothesis of financial markets, but also includes a theory of the business cycle. While the financial instability hypothesis (FIH) 
is rooted in the work of Minsky, the Post-Keynesian institutionalists have recently made fruitful extensions by combining consumer spending and inequality into their analyses. ${ }^{19}$

The FIH can be seen as an alternative to the notion of efficient markets, which (as suggested earlier) was popular in economics and finance before the recent crisis. According to the perspective of efficient markets, participants in financial markets are not, as a group, predisposed to overconfidence and other biases. In contrast, the FIH treats bubbles and crises as recurrent features of the economic landscape. A key difference is that analyses rooted in an efficient-markets viewpoint apply probability analysis and risk-management tools, while the FIH is designed for decisions that are fundamentally uncertain. As a result, the FIH accommodates herd behavior and sudden changes in expectations; it is also broadly compatible with the insights of Andrew W. Lo (originator of the "adaptive markets hypothesis") and other contributors to behavior finance. ${ }^{20}$

According to Minsky's FIH, the financial structure of our economy becomes more and more fragile over a period of prosperity. Minsky (1986, 206-213) describes that process as the evolution from "hedge" to "speculative" and, eventually, to "Ponzi" financing. At the start of an economic expansion, business enterprises usually take a conservative approach to financing, so their cash flow is generally sufficient to cover their full debt obligations (interest and principal); this is hedge finance. However, enterprises in profitable and growing segments of the economy are rewarded for taking on increasing amounts of debt, so more and more firms take on debts that require refinancing when the principal is due for repayment; this is speculative finance. The success of such firms (and the economic expansion) emboldens others, and some enterprises eventually pile up so much debt that they require refinancing merely to make interest payments; this is Ponzi finance (named after financial schemer Charles Ponzi). In the end, some Ponzi units cannot sustain themselves, sending shockwaves through the economy that can diminish business expectations, provoke deleveraging, and trigger a debt-deflation. ${ }^{21}$

The FIH includes an investment theory of the business cycle. As in Keynes (1937), particular attention is given to investment because it is generally the most volatile component of aggregate demand. Investment depends on the price of capital assets in relation to the price of current output and on financing demand and credit availability, which means that investment

\footnotetext{
${ }^{19}$ For references on the FIH, see footnote 3 above.

${ }^{20}$ For further discussion of the work of Lo and its compatibility with PKI, see Brazelton and Whalen (2011).

${ }^{21}$ After some time, of course, hedge financing again dominates_and the cycle begins anew.
} 
rests heavily on expectations about an uncertain future. As an economy evolves away from hedge and toward Ponzi finance, investment increases-which means that aggregate demand, employment, and output rise, and recovery gives way to an expansion and boom. Later, financial fragility reaches its limit, resulting in a financial crisis that -in the absence of adequate countervailing public-policy action or institutional containment mechanisms-becomes an economic downturn and perhaps even a depression. As inventories are depleted and capital assets wear out or become obsolete, expectations will eventually favor renewed investment, but (as mentioned earlier) the economy can be stuck far below potential for some time.

Minsky's FIH provides important insight into the recent global financial crisis and Great Recession, but recent events also highlight the need for extensions to his analysis. ${ }^{22}$ PostKeynesian institutionalists have responded by bringing consumer spending and inequality into their analyses. For example, Fadhel Kaboub (2011) stresses that although mortgage-related debt played a major role in the Great Recession, that downturn was worsened by significant US income inequality and high levels of other forms of consumer indebtedness (such as credit card debt), both of which can be traced in large part to decades of wage stagnation. ${ }^{23}$

\section{PKI Builds on the Schumpeter-Minsky Theory of Capitalist Development}

The money manager capitalism that Minsky highlighted while working at the Levy Economics Institute is the latest stage in a theory of capitalist development that Minsky acquired while studying with Schumpeter at Harvard. ${ }^{24}$ According to that theory, capitalism in the US passed through four stages_-commercial capitalism, industrial capitalism, financial capitalism, and managerial capitalism—before money manager capitalism emerged in the early 1980s (Minsky 1996, 1993, 1990).

The Schumpeter-Minsky theory of capitalist development is institutionally grounded and finance driven. It holds that capitalist development is shaped by the institutional structure and that this structure is always evolving in response to profit-seeking activity. The financial system takes on special importance in the theory because that system is particularly prone to innovation.

\footnotetext{
${ }^{22}$ For analyses that apply the FIH to the recent crisis, see, for example, Barbera (2009), Fernandez et al. (2008), and Whalen (2011a, 2007).

${ }^{23}$ For discussions of instability and inequality, see also Brown (2008), Tymoigne (2007), Weller and Sabatini (2007), Wunder (2012), and Zalewski and Whalen (2010).

${ }^{24}$ Until his death in 1950, Schumpeter was the adviser of Minsky's doctoral dissertation.
} 
Moreover, finance and industrial development are in a symbiotic relation, so financial evolution exerts a strong influence on the evolution of the economic system as a whole (Whalen 2001). ${ }^{25}$

Money manager capitalism is characterized by the strong influence of institutional investors upon economic decision-making, by increased worker insecurity and rising income inequality, and by a fast pace of financial innovation. The aim of money managers, and the sole criterion by which they are judged, is maximization of the value of investments made by fund holders. Business leaders, therefore, have responded by becoming highly sensitive to short-term profits and the stock-market valuation of their firms. This has led to a wide variety of corporate restructurings, as well as to labor force downsizing, outsourcing, and offshoring, all of which have fueled worker insecurity and income inequality. Money manager capitalism has also fueled financial innovation, especially securitization. ${ }^{26}$

\section{PKI Appreciates the Inevitable and Creative Role of Government in Economic Life}

Conventional economics maintains that the proper role of government is to serve as a corrective entity - that is, to correct for market failures such as the existence of externalities. In contrast, PKI views the government as an unavoidably creative entity. PKI also recognizes that government's creative effort can be directed toward at least three different conceptions of efficiency, and that public policy may often be shaped by other important considerations, as well.

Government is an inevitable participant in economic life. Human conflict and power struggles seldom remain private matters. As Commons $(1909,79)$ wrote, "The contest of economic classes or interests enters the field of politics, the laws of the land, and even the very framework of government." Indeed, governments exist to address such conflict. In fact, this is reflected in the Declaration of Independence, which makes clear at the outset that governments must be established to secure the liberties of individuals.

Securing liberties entails more than enumerating and enforcing rights; it requires establishing limits. Setting boundaries on freedom in economic and social life is a fundamental role of government. No society can offer boundless and absolute freedom for all—ensuring the

\footnotetext{
${ }^{25}$ Key questions to be asked at each stage of development are: What is being financed? What is the pivotal source of external financing? And, what is the balance of economic power between those in business and banking?

${ }^{26}$ For further discussion of money manager capitalism — and its flipside, worker insecurity — see, for example, Liang (2011), Minsky and Whalen (1996-1997), Tavasci and Toporowski (2010), Van Lear (2002), Whalen (2008b, 2002, 1997), Wray (2009), Zalewski (2004, 2002), and Zalewski and Whalen (2010).
} 
liberties of one person most often requires restricting the liberties of another. As Milton Friedman (1982 [1962], 25-26) acknowledged in Capitalism and Freedom, "My freedom to move my fist must be limited by the proximity of your chin."

However, government is more than an umpire. Society does not merely establish a set of constitutional liberties and limits and then look to government to simply enforce the "rules of the game." Because there are always new and unexpected conflicts in economic and social life, the "game" is always evolving. That means legislative, administrative, and judicial decisions must give rights their specific meanings, and those meanings can evolve over time. ${ }^{27}$

By setting an ever-evolving legal framework, government plays a creative role in all aspects of the economic process. For example, it is not enough to say that government must foster competitive markets; government is regularly called on to address the appropriate nature and scope of competition. The legal framework regulating competition is always evolving, and competing interests constantly seek to influence that evolution by pressing for the legitimacy of their rights and freedoms. As institutional economist Warren J. Samuels (1989, 167) writes, "Government is deeply involved in the [ongoing] definition and creation of the economy."28

Government also plays a constructive economic role that extends beyond making (and enforcing) rules that liberate or restrain people and organizations. Through a wide range of activities-including construction of major public facilities and stabilization of the economy, for example-government accomplishes what the private sector cannot. In addition, by providing public education and other services that improve people's abilities and opportunities, government actually expands individual liberties. ${ }^{29}$

PKI recognizes that freedom through government is as essential as freedom from government. To be sure, government action is not always broadly beneficial or without unintended consequences. But in a world where institutions matter, the state's creative role is seen as vital to economic performance and individual wellbeing. A similar view was expressed more than a century ago by the founders of the American Economic Association $(1887,35)$,

\footnotetext{
${ }^{27}$ For discussions of the evolving legal foundations of capitalism, see, for example, Commons (1924) and Schmid (1960).

${ }^{28}$ For a similar perspective, see Schmid (1999).

${ }^{29}$ For similar views-expressed in the realms of economics and politics, respectively-see Commons $(1934,73)$ and Nicholay $(1894,180)$.
} 
who began their Statement of Principles with the following: "We regard the state as an agency whose positive assistance is one of the indispensible conditions of human progress." 30

PKI also recognizes that government action can be directed toward at least three types of efficiency — Smithian, Keynesian, and Schumpeterian. The first is the standard, allocative efficiency of conventional microeconomics (rooted, of course in the economics of Adam Smith). The second is the macroeconomic efficiency associated with full employment (that is, when actual output is equal to potential output). The third is the dynamic, or adaptive, efficiency of evolutionary economics. According to James Ronald Stanfield, dynamic efficiency focuses on economic growth over time and requires an institutional complex that "can assimilate change in an orderly fashion in which conflict is contained and largely resolved" (Stanfield 2006, 253). While dynamic efficiency is the type that most closely fits with the institutionalist foundation outlined in this article, PKI accepts that all three conceptions of efficiency have a role to play in public policy_and that policy may be shaped by other considerations as well (social justice, for example). ${ }^{31}$

\section{DIRECTIONS FOR FURTHER RESEARCH}

Because PKI is a relatively new intellectual tradition, there is much room for further research. Foundations need strengthening. Existing theories need refining and updating. And policy insights need sharpening.

The foundations of PKI would benefit from further attention to methodology (or philosophical grounding) and to methods. Insight relevant to the further development of PKI methodology can be found in psychology, sociology, neuroscience, and related disciplines. ${ }^{32}$ In addition, Fernández-Huerga (2008) offers a recent contribution to this part of the PKI literature, giving special attention to motivation, cognition, and decision-making. Insight on methods can be found in the system dynamics literature and in Godley's pioneering work on stock-flow consistent modeling (Lavoie and Zezza 2012; Godley and Lavoie 2007), and Tauheed (2011) shows how such methods can bolster the foundations and utility of PKI. ${ }^{33}$

\footnotetext{
${ }^{30}$ A similar perspective can be found in Durkheim (1933 [1893], xxiii, 386-387).

${ }^{31}$ For further discussion of other considerations, see, for example, Marangos and Whalen $(2011,166-67)$ and Minsky and Whalen (1996-1997, 161-162).

${ }^{32}$ For a modest examination of sociology, see Brazelton and Whalen (2011: 42-43).

${ }^{33}$ For another constructive examination of methods, see Atkinson and Oleson (1996), and for a recent application, see Whalen (2011b).
} 
The theories of PKI will always need refining and updating because they are grounded in a dynamic institutional reality. However, the following aspects of theory deserve special attention. The FIH and the Schumpeter-Minsky theory of capitalist development need to be more fully integrated, especially since business cycles are both a cause and consequence of structural economic change. The study of money-manager capitalism needs to be more closely connected to literature on financialization and globalization. The relationship between moneymanager capitalism and economic insecurity (and income inequality) deserves more attention. And PKI needs to give particular attention to the challenges of global economic development and sustainability. ${ }^{34}$

PKI offers important insights on public policy—its analyses have led to development of innovative policy options on economic stabilization and financial regulation, for example—but achieving sustainable and broadly shared prosperity in a dynamic economy will require considerably more policy analysis. One challenge ahead is the need to contain financial fragility while preserving economic dynamism. Another is the challenge of meeting near-term socioeconomic needs while addressing long-term fiscal challenges. Those are daunting challenges, but PKI—like both institutional economics and Post-Keynesianism—was created to contribute to the resolution of real-world problems, not to engage in a purely academic exercise. ${ }^{35}$

\section{CONCLUSION: A PROMISING FUTURE}

PKI, which draws heavily on the contributions of Hyman Minsky, does not have all the answers needed to reform economic theory and policy after the Great Recession. Nevertheless, it combines insights from two traditions that have been asking the right questions for years-and it has proven itself relevant to the recent global financial crisis and prescient about economic insecurity and income inequality. There is much more to do, but institutionalism and PostKeynesianism have reached their common destination, and PKI offers a promising way forward.

\footnotetext{
${ }^{34}$ For valuable insights on development and sustainability from perspectives compatible with PKI, respectively, see Tavasci and Toporowski (2010) and Holt et al. (2009). For further discussion of sustainability, see Senge et al. (2008).

${ }^{35}$ For policy insights from a PKI perspective, as well as a further discussion of the future of PKI, see Whalen (2011c).
} 


\section{REFERENCES}

Appelbaum, E. 1979. “The Labor Market.” In A.S. Eichner (ed.), A Guide to Post-Keynesian Economics. White Plains, NY: M.E. Sharpe, 100-119.

Atkinson, G., and T. Oleson. 1998. "Commons and Keynes: Their Assault on Laissez Faire." Journal of Economic Issues 32(4): 1019-1030.

_ 1996. "Institutional Inquiry: The Search for Similarities and Differences." Journal of Economic Issues 30(3): 701-713.

Atkinson, G., and C.J. Whalen . 2011. "Futurity: Cornerstone of Post-Keynesian Institutionalism." In C.J. Whalen (ed.), Financial Instability and Economic Security after the Great Recession. Cheltenham, UK: Edward Elgar, 53-75.

American Economic Association. 1887. "Constitution." In Publications of the American Economic Association, Volume 1. Baltimore: American Economic Association, 35-37.

Barbera, R. 2009. The Cost of Capitalism: Understanding Market Mayhem and Stabilizing our Economic Future. New York: McGraw Hill.

Brainard, W.C., and J. Tobin. 1968. "Pitfalls in Financial Model Building." American Economic Review 58(2): 99-122.

Brazelton, W.R. 1981. "Post-Keynesian Economics: An Institutional Compatibility?" Journal of Economic Issues 15(2): 531-542.

Brazelton, W.R., and C.J. Whalen. 2011. "Towards a Synthesis of Institutional and PostKeynesian Economics." In C.J. Whalen (ed.), Financial Instability and Economic Security after the Great Recession. Cheltenham, UK: Edward Elgar, 28-52.

Brown, C. 2008. Inequality, Consumer Spending, and the Saving Puzzle. Cheltenham, UK: Edward Elgar.

Caballero, R.J. 2010. "Macroeconomics after the Crisis: Time to Deal with the Pretense-ofKnowledge Syndrome." Journal of Economic Perspectives 24(4): 85-102.

Chasse, J.D. 1991. "John R. Commons and John Maynard Keynes: Two Philosophies of Action." Journal of Economic Issues 25(2): 441-448.

Commons, J.R. 1934. Institutional Economics: Its Place in Political Economy. New York, Macmillan.

-1924. Legal Foundations of Capitalism. New York: Macmillan.

- 1909. "American Shoemakers, 1648-1895: A Sketch of Industrial Evolution." Quarterly Journal of Economics 24(1): 39-84.

Crotty, J.R. 1990. "Keynes on the Stages of Development of the Capitalist Economy: The Institutional Foundation of Keynes's Methodology." Journal of Economic Issues 24(3): 761-780. 
Dillard, D. 1986. "The Institutional Principle of the Principles of Economics." Journal of Economic Issues 20(2): 355-363.

- 1980. "A Monetary Theory of Production: Keynes and the Institutionalists." Journal of Economic Issues 14(2): 255-273.

Dugger, W.M. 1996. "Redefining Economics: From Market Allocation to Social Provisioning." In C.J. Whalen (ed.), Political Economy for the $21^{\text {st }}$ Century. Armonk, NY: M.E. Sharpe, $31-43$.

Durkheim, E. 1933 [1893]. The Division of Labor in Society. Trans. George Simpson. New York: The Free Press.

Ferandez, L., F. Kaboub, and Z. Todorova. 2008. "On Democratizing Financial Turmoil: A Minskyan Analysis of the Subprime Crisis." Working Paper No. 548. Annandale-onHudson, NY: Levy Economics Institute of Bard College.

Fernández-Huerga, E. 2008. "The Economic Behavior of Human Beings: The Institutional/PostKeynesian Model.” Journal of Economic Issues 43(3): 709-726.

Folbre, N. 2001. The Invisible Heart: Economics and Family Values. New York: The New Press.

Foster, J.F. 1981. "The Fundamental Principles of Economics.” Journal of Economic Issues 15(4): 937-942.

Friedman, M. 1982 [1962]. Capitalism and Freedom. Chicago: University of Chicago Press.

Galbraith, J.K. 1979. "The Valid Image of the Modern Economy, and Power and the Useful Economist.” In Annals of an Abiding Liberal. New York: Meridian, 3-19 and 353-371.

Godley, W., and M. Lavoie. 2007. Monetary Economics: An Integrated Approach to Credit, Money, Income, Production, and Wealth. Houndmills, UK: Palgrave Macmillan.

Gordon, R.A. 1976. "Rigor and Relevance in a Changing Institutional Setting." American Economic Review 66(1): 1-14.

Hall, P.A., and D. Soskice (eds.). 2001. Varieties of Capitalism: The Institutional Foundations of Comparative Advantage. New York: Oxford University Press.

Hatzius, J., and S. Stehn. 2011a. "A More Downbeat Message from our Financial Balances Model." US Daily. Goldman Sachs Global Economics, Commodities and Strategy Research.

—. 2011b. "Private Boost, Public Restraint." US Economics Analyst. Goldman Sachs Global Economics, Commodities and Strategy Research (24 June).

Holt, R., S. Pressman, and C.L. Spash (eds.). 2009. Post-Keynesian and Ecological Economics: Confronting Environmental Issues. Cheltenham, UK: Edward Elgar.

Kaboub, F. 2011. "Understanding and Preventing Financial Instability: Post-Keynesian Institutionalism and Government as Employer of Last Resort.” In C.J. Whalen (ed.), 
Financial Instability and Economic Security after the Great Recession, Cheltenham, UK: Edward Elgar, 73-90.

Kates, S. 2011. "Subverting Say's Law: Harlan McCracken and the Commons-Keynes connection." C.J. Whalen (ed.), Financial Instability and Economic Security after the Great Recession. Cheltenham, UK: Edward Elgar, 15-27.

Keller, R.R. 1983. "Keynesian and Institutional Economics: Compatibility and Complementarity?" Journal of Economic Issues 17(4): 1087-1095.

Keynes, J.M. 1937. "The General Theory of Employment.” In Quarterly Journal of Economics 51(2): 209-223.

Krugman, P. 2009a. "The Return of Depression Economics, Part III: The Night They Reread Minsky." Lecture delivered at the London School of Economics and Political Science, June 10.

— 2009b. "How Did Economists Get It So Wrong?" The New York Times, September 2. http://www.nytimes.com/2009/09/06/magazine/06Economic-t.html

Lavoie, M., and G. Zezza (eds.). 2012. The Stock-Flow Consistent Approach: Selected Writings of Wynne Godley. Houndmills, UK: Palgrave Macmillan.

Lee, F.S. 1996. "Pricing and the Business Enterprise." In C.J. Whalen (ed.), Political Economy for the $21^{\text {st }}$ Century: Contemporary Views on the Trend of Economics. Armonk, NY: M.E. Sharpe, 87-102.

Liang, Y. 2011. "Money-Manager Capitalism, Capital Flows, and Development in Emerging Economies: A Post-Keynesian Institutionalist Analysis.” In C.J. Whalen (ed.), Financial Instability and Economic Security after the Great Recession. Cheltenham, UK: Edward Elgar, 197-204.

Marangos, J., and C.J. Whalen. 2011. "Evolution without Fundamental Change: The Washington Consensus on Economic Development and Its Significance for PostKeynesian Institutionalism.” In C.J. Whalen (ed.), Financial Instability and Economic Security after the Great Recession. Cheltenham, UK: Edward Elgar, 153-178.

Marshall, R. 1983. "Comments on the Institutionalist View of Reaganomics.” Journal of Economic Issues 17(2): 503-506.

May, A.M. 1996. “The Challenge of Feminist Economics.” In C.J. Whalen (ed.), Political Economy for the $21^{\text {st }}$ Century: Contemporary Views on the Trend of Economics. Armonk, NY: M.E. Sharpe, 67-85.

Minsky, H.P. 1969. "Private Sector Asset Management and the Effectiveness of Monetary Policy: Theory and Practice." The Journal of Finance 24(2): 223-228.

—. 1975. John Maynard Keynes. New York: Columbia University Press. . 1982. Can 'It' Happen Again? Essays in Instability and Finance. Armonk, NY: M.E. Sharpe. 
— 1986. Stabilizing an Unstable Economy. New Haven: Yale University Press.

1990. "Schumpeter: Finance and Evolution." In A. Heertje, and M. Perlman (eds.), Evolving Technology and Market Structure. Ann Arbor: University of Michigan Press: $51-74$.

—. 1992. "The Financial Instability Hypothesis." Working Paper, No. 74. Annandale-onHudson, NY: Levy Economics Institute of Bard College.

_ . 1993. "Schumpeter and Finance." In S. Biasco, A. Roncaglia, and M. Salvati (eds.), Markets and Institutions in Economic Development. New York: St. Martin's, 103-115.

_. 1996. "Uncertainty and the Institutional Structure of Capitalist Economy." In Journal of Economic Issues 30 (2): 357-368.

Minsky, H.P., and C.J. Whalen. 1996-1997. "Economic Insecurity and the Institutional Prerequisites of Successful Capitalism." Journal of Post-Keynesian Economics 19(2): $155-170$.

Mitchell, W.C. 1941. Business Cycles and Their Causes. Berkeley: University of California Press.

Nicholay, J.G. 1894. Abraham Lincoln: Complete Works. New York: The Century Company.

Niggle, C. 2006. "Evolutionary Keynesianism: A Synthesis of Institutionalist and PostKeynesian Macroeconomics." Journal of Economic Issues 40(2): 405-412.

Peterson, W.C. 1977. "Institutionalism, Keynes and the Real World." Journal of Economic Issues 11(2): 201-221.

Piore, M.J., and C.F. Sable. 1984. The Second Industrial Divide: Possibilities for Prosperity. New York: Basic Books.

Pollin, R. 2008. "We're All Minskyites Now." The Nation, (17 November), 6-7.

Samuels, W.J. 1989. "Some Fundamentals of the Economic Role of Government." In W.J. Samuels (ed.), Fundamentals of the Economic Role of Government. Westport, Connecticut: Greenwood Press, 167-172.

Senge, P., B. Smith, N. Kruschwitz, J. Laur, and S. Schley. 2008. The Necessary Revolution: How Individuals and Organizations are Working Together to Create a Sustainable World. New York: Broadway Books.

Schmid, A.A. 1999. "Government, Property, Markets...In That Order...Not Government Versus Markets." In N. Mercuro, and W.J. Samuels (eds.) The Fundamental Interrelationships between Government and Property. Stamford: JAI Press, 237-242.

-1960. Evolution of Michigan Water Laws: Response to Economic Development. East Lansing: Michigan Agricultural Experiment Station.

Schumpeter, J.A. 1976 [1942]. Capitalism, Socialism, and Democracy. New York: Harper Torchbooks. 
Skidelsky, R. 2003. John Maynard Keynes, 1883-1946: Economist, Philosopher, Statesman. New York: Penguin Books.

Stanfield, J.R. 2006. "From OIE and NIE toward EE: Remarks upon Receipt of the VeblenCommons Award." Journal of Economic Issues 40(2): 249-259.

Stiglitz, J.E. 2010. Freefall: America, Free Markets, and the Sinking of the World Economy. New York: W.W. Norton and Company.

Summers, L.H. 2011. Conversation on New Economic Thinking. Institute for new Economic Thinking, April 4. http://ineteconomics.org/people/participants/larry-summers

Tauheed, L. 2011. "A Proposed Methodological Synthesis of Post-Keynesian and Institutional Economics.” In Journal of Economic Issues 45(4): 819-838.

Tavasci, D. and J. Toporowski. 2010. Minsky, Crisis, and Development. Houndmills, UK: Palgrave Macmillan.

Thompson, C.C. (ed.). 1967. Institutional Adjustment: A Challenge to a Changing Economy. Austin, TX: University of Texas Press.

Todorva, Z.K. 2009. Money and Households in a Capitalist Economy: A Gendered PostKeynesian-Institutional Analysis. Cheltenham, UK: Edward Elgar.

Tymoigne, E. 2003. “Keynes and Commons on Money.” Journal of Economic Issues 37(3): $527-545$.

— 2007. "A Hard-Nosed Look at Worsening US Household finance." Challenge 50(4): $88-111$.

Van Lear, W. 2002. A Populist Challenge to Corporate Capitalism. River Edge, New Jersey: World Scientific.

Waller, W. 2005. "Accidental Veblenian, Intentional Institutionalist and Inevitable Feminist." Journal of Economic Issues 39(2): 327-334.

Weller, C., and K. Sabatini. 2007. "The Financial Vulnerability of Families." Challenge 50(3): $72-972$.

Whalen, C.J. 1997. "Money-Manager Capitalism and the End of Shared Prosperity." Journal of Economic Issues 31(2): 517-525.

— 2001. "Integrating Schumpeter and Keynes: Hyman Minsky's Theory of Capitalist Development." Journal of Economic Issues 35(4): 805-823.

- 2002. "Money-Manager Capitalism: Still Here, But Not Quite as Expected.” Journal of Economic Issues 36(2): 401-406.

— 2007. "The U.S. Credit Crunch of 2007: A Minsky Moment." Public Policy Brief No. 92. Annandale-on-Hudson, NY: Levy Economics Institute of Bard College. 
- 2008a. "John R. Commons and John Maynard Keynes on Economic History and Policy: The 1920s and Today." Journal of Economic Issues 42(1): 225-242.

- 2008b. "Post-Keynesian Institutionalism and the Anxious Society." In S.S.Batie, and N. Mercuro (eds.), Alternative Institutional Structures: Evolution and Impact. New York: Routledge, 273-299.

— 2011a. "Rethinking Economics for a New Era of Financial Regulation: The Political Economy of Hyman Minsky." In Chapman Law Review 15(1): 149-169.

—. 2011b. "Union Engagement in Western New York Economic Development: An Institutional Analysis.” In Advances in Industrial and Labor Relations, Vol. 18. Bingley, UK: Emerald, 177-214.

- 2011c. Financial Instability and Economic Security after the Great Recession. Cheltenham, UK: Edward Elgar.

Wilber, C.K., and K.P. Jameson. 1983. An Inquiry into the Poverty of Economics. Notre Dame, Indiana: University of Notre Dame Press.

Wunder, T.A. 2012. "Income Distribution and Consumption Driven Growth: How Consumption Behaviors of the Top Two Income Quintiles Help to Explain the Economy." Journal of Economic Issues 46(1): 173-191.

Wray, L.R. 2009. "The Rise and Fall of Money Manager Capitalism: A Minskian Approach.” Cambridge Journal of Economics 33(4): 807-828.

Zalewski, D.A. 2002. "Retirement Insecurity in the Age of Money-Manager Capitalism." Journal of Economic Issues 36(2): 349-356.

- 2004. "Wealth and Power: Ethical Implications of Executive Compensation Since the 1980s." In D.P. Champlin, and J.T. Knoedler (eds.), The Institutionalist Tradition in Labor Economics. Armonk, NY: M.E. Sharpe, 286-296.

Zalewski, D.A, and C.J. Whalen. 2010. "Financialization and Income Inequality: A PostKeynesian Institutionalist Analysis.” Journal of Economic Issues 44(3): 757-777.

Zandi, M. 2011. "Growth in the Balance." Précis U.S. Macro, Moody's Analytics, 16(2): 2-3. 